\title{
Peran dan Kiprah Haji Patarai Daeng Ma’ruppa, 1951-2003
}

\author{
Ernawati B, Mustari Bosra, Jumadi \\ Prodi Pendidikan Sejarah Fakultas Ilmu Sosial Universitas Negeri Makassar \\ erna20872@gmail.com
}

\begin{abstract}
Abstrak
Penelitian ini bertujuan untuk mengetahui latar belakang kehidupan Haji Patarai Daeng Ma'ruppa, Peran dan Kiprahnya sebagai pegawai peternakan dan kepala Desa/Lurah Bontonompo, serta Peran dan Kiprahnya sebagai pemangku adat dan pelestari Gaukanga di Bontonompo. Penelitian ini merupakan penelitian yang bersifat deskriptif-analisis dengan menggunakan metode penelitian sejarah melalui tahap heuristik, kritik, interpretasi dan historiografi. Hasil penelitian ini menunjukan bahwa Haji Patarai Daeng Ma'ruppa adalah keturunan Karaeng Polombangekeng. Menjadi teladan dalam masyarakat Bontonompo pada masa pemerintahannya. Selain sebagai teladan dalam bidang pemerintahan, Haji Patarai Daeng Ma'ruppa juga merupakan seorang pemerhati dan pelestari budaya. Denga Peran dan Kiprah sebagai pemangku adat dan Gaukanga di Bontonompo. Kesimpulan bahwa Haji Patarai Daeng Ma'ruppa memiliki Peran dan Kiprah dalam pemerintah dan Pelestarian Gaukanga serta menjadi Pemangku Adat di Bontonompo.
\end{abstract}

\section{Kata Kunci: Peran, Kiprah, dan Haji Patarai Daeng Ma'ruppa}

\begin{abstract}
This study aims to determine the background of the life of Haji Patarai Daeng Ma'ruppa, his role and progress as an employee of animal husbandry and the head of Bontonompo Village / Village, and his role and role as customary and preserver of Gaukanga in Bontonompo. This research is a descriptive-analysis study using historical research methods through the heuristic, critical, interpretation and historiographic stages. The results of this study indicate that the Daeng Ma'ruppa Patarai Hajj is a descendant of Karaeng Polombangekeng. Being a role model in the Bontonompo community during his reign. Aside from being an example in the field of government, Haji Patarai Daeng Ma'ruppa is also a cultural observer and preserver. With the role and role of the indigenous people and Gaukanga in Bontonompo. The conclusion is that Haji Patarai Daeng Ma'ruppa has a role and role in the government and the preservation of Gaukanga as well as being a traditional holder in Bontonompo.
\end{abstract}

\section{Keywords: Role, Gait, and Haji Patarai Daeng Ma'ruppa}

\section{A. Pendahuluan}

Sejarah Indonesia selalu dihubungkan dengan sejarah Kerajaan-kerajaan yang pernah ada dan eksis di Nusantara. Indonesia sesungguhnya adalah kata politik untuk mengikat Pulau-pulau yang terbentang dari Sabang sampai Marauke. Pulau-pulau yang terbentang luas itu sebelum menjadi suatau kesatuan (NKRI) merupakan bekas wilayah yang disebut
Hindia Belanada dibawah kekuasaan Belanda. (Sahajuddin, 2009)

Sistem pemerintahan di Gowa sejak awal terbentuknya adalah sistem pemerintahan kerajaan dimana kekuasaan tertinggi berada di tangan seorang Raja (Sombaya ri Gowa). Dalam menjalankan pemerintahannya, dibantu oleh beberapa orang pembatunya. (Kila, 2004) Dengan sistem pemerintahan sebelum dilebur atau diubah menjadi desa pasca pergeseran 
tatanan kebangsaan dari kerajaan menjadi republik, kepemimpinan kerajaan tojeng, kepemimpinan murni dan lansung yang terdapat di desa-desa, menurunkan gelargelar yang berbeda-beda menurut sejarah desa masing-masing. Adapun gelar-gelar penguasa desa terdapat dalam lingkungan kerajaan gowa pada fase terakhir perkembangannya, dapat digambarkan meliputi : (1). Gallarang, seperti Gallarang Mangasa, Gallarang Tombolo. (2). Angrong Guru, seperti Angrog Guru Lempangngan, Angorong Guru Boncobalang dan Angrong Guru Bontonompo.(3). Daeng, seperti Daeng palangga, Daeng Paku. (4). Jannang, seperti Jannang Gentungan, Jannag Data. (5). Aruk, seperti Aruk Pao (Wahid, 2007).

Pada tahun 1868 Belanda sudah beberapa kali menyerang Bontonompo, tapi tidak dapat ditaklukkan. Belanda berupaya agar Gaukangan yang menjadi simbol kekuatan masyarakat Bontonompo ini di rampas, peperangan berlansung seru, yang terkenal dengan "Bunduka ri Mangasaya” (perang di Mangasa). Perang ini melibatkan masyarakat Bontonompo yang di pimpin oleh I YUSENG DAENG MALLINGKAI, yang merupakan Angrong Guru pertama Bontonompo dan mendapat Gelar "Kare" terakhir. Tapi malang nasibnya, I Yuseng Daeng Mallingaki di tawan kemudian di hukum pancung sehingga menemui ajalnya, lalu di kuburkan di kampung Buttu-burtu, sekarang di kenal sebagai kuburan patanna butta (kuburannya yang punya tanah). Demikian pula, Gaukanga yang ada di Bontonompo dirampas untuk dibawa ke raja Gowa untuk disimpan.

Untuk mengaggalkan rencana Belanda tersebut dan dalam rangka perjuangan menegakkan, membela dan mempertahankan kemerdekaan. Maka ketika organisasi perjuangan Gerakan Muda Bajeng dibentuk atau diresmikan di kota Palleko (Polombangkeng) pada tanggal 16 Oktober 1945. Dibentuk pula cabang organisasi perjuangan Gerakan Muda Bajeng untuk daerah Bontonompo dan dibawah pimpinan Kende Daeng Sutte.
Ketika itu ia memimpin rombongan dari Bontonompo dalam menghadiri rapat umum peresmian berdirinya organisasi perjuangan Gerakan Muda Bajeng di Palleko (Polombangkeng). Dan sejak itu dinyatakan bahwa daerah Bontonompo adalah bahagian yang tak terpisahkan dari wilayah Republik Indonesia.

Demikian pula ketika organisasi perjuangan Gerakan Muda Bajeng berubah atau menjelma menjadi Laskar Lipang Bajeng pada tanggal 2 April 1946. Dibentuk pula Dewan pengurus Daerah atau ketua Muda Laskar Lipang Bajeng untuk daerah Bontonompo di bawah pimpinan Kende Daeng Sutte dan Djamalong Daeng Rowa. Dengan demikian, maka perjuangan dalam menegakkan, membela dan mempertahankan kemerdekaan di daerah Sulawesi Selatan, tampaknya merupakan suatu kesatuan yang tak terpisahkan satu dengan yang lainnya. Karena organisasi perjuangan Laskar Lipan Bajeng misalnya, bukan hanya meliputi daerah Bontonompo, Limbung, Pallangga, Malakaji, Galesong, Sanrobone, Topejawa, Laikang, Makassar dan sekitarnya, Gowa (seberang Je'neberang, dan lain-lain). Lebih-lebih setelah terbentuknya Laskar Pemborontak Rakyat Indonesia Sulawesi (LAPRIS) yang meliputi ghampir seluruh daerah Sulawesi Selatan. (Muhamad Arfah, 1995)

Paharuddin Daeng Nyonri merupakan permata utama Butta Jipang yang sekaligus sahabat dari Haji Patarai Daeng Ma'ruppa yang bersama-sama sebagai satu pilar atau tokoh Bontonompo yang bersahaja. Punya jejak pengabdian yang cukup gemilang di ranah pemerintahan. (Mala'lang, 2018)

Sejak terbentuknya organisasi perjuangan di daerah Bontonompo, telah terjadi beberapa kali kontak senjata antara para pejuang di satu pihak dengan serdadu Belanda di lain pihak. Pada bulan November 1946, pasukan Lipang Bajeng bagian Bontonomopo dengan kekuasaan sekitar 47 orang anggota pasukan di bawah pimpinan Sonrong Daeng Mangung, Kende Daeng Sutte, Daeng Tangnga, dan Lahayya, 
melakukan penyerangan terhadap kantor Distrik Bontonompo yang yang di kawal sekitar 20 orang pasukan polisi NICA (Belanda). Setelah terjadi pertempuran beberapa saat akhirnya pihak musuh (polisi NICA) mengundurkan diri dan meninggalkan pos atau masyarakat. Kesempatan tersebut dimanfaatkan oleh para pejuang untuk membakar habis Kantor Distrik Bontonompo di Rappokaleleng tersebut. Pada pertempuran itu tidak ada korban jiwa di kedua belah pihak.

Lipang Bajeng tak hanya menyengat musuh tentara Belanda dan Jepang di Polombangkeng atau Bajeng Gowa, juga di Bontonompo. Pertama berdirinya Gerakan Muda Bajeng di Polombangkeng, di Bontonompo sudah dibentuk cabang yang dipelopori oleh tokoh pejuang yang cinta pada kemerdekaan. Untuk mengetahui secara jelas bagaimana Kiprah tokoh pejuang Bontonompo.

Haji Patarai Daeng Ma'ruppa lahir di Bontonompo pada tanggal 2 Februari 1942 dan wafat pada tanggal 14-April-2010 yang terkenal dengan Angrong Guru, Haji patarai Daeng Ma'ruppa beristrikan yang bernama Hajja Hadiyah Daeng Labbi anak dari Iman besar Bontonompo yaitu Maddatuang Kare' Tawang.

Haji Patarai Daeng Ma'ruppa yang identik dengan "perekat hati dan magnet budaya Bontonompo" Haji patarai Daeng Ma'ruppa adalah sosok laki-laki yang tidak mengenal kata menyerah dalam kehidupannya dan pengabdianya terhadap bangsa indonesia dan rakya gowa terkhusu terhadap masyarakat Bontonompo tidak dapat dipungkri lagi. Beliau adalah kepala desa Bontonompo pada tahun 1965-1979 kemudian dirubah menjadi kelurahan Bontonompo pada tahun 1979-1987. Haji patarai Daeng Ma'ruppa atau akrab dikenal dekat dengan rakyatnya. Anak dari I Manynyaurang Daeng Sibali Genetika Gallarang Bontonompo juga merupakan pemnagku "Angrong Guru" terakhir Bontonompo sebelumnya dilebur atau di ubah menjdi desa pasca pergeseran tatanan kebangsaan dari kerajaan menjadi republik. (Mala’lang, 2018)

Jejak dan peranan Haji Patarai Daeng Ma'ruppa meliputi: (1), PNS dinas peternakan kota makassar pada tahun 1951. (2), Angrong Guru Bontonompo yang ke XI mulai tanggal 24-12-1962 sampai 1967. (3), Kepala desa Bontonompo Kecamatan Bontonompo Kab.Gowa tahun 1967-1981. (4), Lurah Bontonompo Kecamatan Bontonompo Kab.Gowa tahun 1981-1987. (5), Ketua K.U.D Bontonompo tahun 1988. (6), Ketua yayasan mesjid besar Raodatussalihin Bontonompo tahun 1996. (7), Pembina "Gaukanga" tahun 1966. (8), Pemangku adat Kecamatan Bontonompo Kab.Gowa 2003 . (Taba, 2019)

Pada usia 86 tahun, 2 bulan, 12 hari tepat pada hari Rabu 14 April 2010 bertempat di Sungguminasa Kab. Gowa kediaman anaknya, Haji patarai Daeng Ma'ruppa menghembuskan nafas terakhirnya disebabkan oleh penyakit yang di derita (asma) kemudian jenasah diantarkan ke kediaman yang telah dibangun bersama sang istri yang bertempat di Jl. Bontonompo Raya No.15 kelurahan Bontonompo Kec. Bontonompo Kab. Gowa dan dikebumikan di kompleks keluarga Bontonompo Kab. Gowa. Di mana $\mathrm{Hj}$ Hadiyah Daeng Labbi yang telah terlebih dahulu dikebumikan di kompleks tersebut.

Haji Patarai Daeng Ma'ruppa meninggalkan 9 orang putra putri dan 9 menantu serta 24 orang cucu dan 13 orang cicit, dan keluarga besarnya dengan luka yang mendalam hal ini disebabkan oleh ketercintaan terhadap sosok Haji Patarai Daeng ma'ruppa yang selama ini menjadi panutan dalam segala hal khusunya jiwa kepemimpinan yang sangat melekat di diri beliau.

Kajian relevan dalam suatu karya ilmiah perlu untuk di telusuri guna mencari tahu apakah ide pokok suatu kajian sudah di angkat oleh penulis lain atau belum. Penelitian ini pada dasarnya di lakukan untuk mengkaji mengenai Kiprah dan 
Peran Haji Patarai Daeng Ma'ruppa Bontonompo di Kecamatan Bonotonompo Kabupaten Gowa.

Kajian relevan dalam penelitian ini adalah beberapa karya yang di terbitkan dalam bentuk buku oleh beberapa orang penulis.Misalnya, karya dari Yusrizal Kamaruddin Daeng Mala'lang dengan judul Sejuta Lentera dari Butta Bontonompo" Dimana membahas tentang tokoh-tokoh pejuang yang terdapat di kecamatan Bontonompo kab.Gowa. buku ini telah memungkinkan penulis mendapatkan tokoh pejuang Angrong Guru Bontonompo. (Mala'lang, 2018) Selanjutnya karya Sugira Wahid yang berjudul "Manusia Makassar" yang membahas mengenai gelar-gelar kepemimpinan yang terdapat di Kab.Gowa dan memungkinkan penelitian ini untuk membahas tentang gelar-gelar yang terdapat Kab. Gowa khusunya Kecamtan Bontonompo. (Wahid, 2007) Selanjutnya karya Syahrul Yasin Limpo,Adi Suryadi Culla. Zainuddin Tika, yang berjudul "profil sejarah. Budaya dan Pariwisata Gowa” yang membahasan sejarah Gowa khusunya Gaukanga ri Bontonompo sedangkan peneliti membahas Gaukanga. (Syahrul Yasin Limpo, 1995)

\section{B. Metode Penelitian}

Dalam satu penulisan karya ilmiah, terdapat cara uyang digunakan untuk menyusun karya ilmiah tersebut. Hal ini sering di sebut sebagai metode. Metode berbeda dengan metedeologi. Menurut Kenneth D. Bailey, metode adalah teknik penelitian atau alat yang di gunakan untuk mengumpulkan data. (Majid, 2018)

\section{Heuristik}

Menurut Kuntowijoyo, ada lima tahapan dalam penelitian sejarah yaitu topik pengumpulan sumber, perifikasi kritik sejarah, interpretasi dan penulisan. Pemilihan topik berkenaan dengan alasan penelitian mengangkat topik ini (berupa kedekatan intelektual dan kedekatan emosional). Pengumpulan sumber berkenaan dengan pengumpulan data informasi. Interpretasi berkenaan dengan pencairan dan keterkaitan makna antara fakta, sedangkan penulisan berkenaan dengan laporan hasil penelitian. (Kuntowijoyo, 2005) Heuristik merupakan langkah awal dari metode penelitian sejarah di mana pada tahap ini seorang mencari dan mengumpulkan penemuan atas sumber sejarah yang memiliki keterkaitan dengan penelitian. Sumber sejarah tersebut dapat memiliki catatan, tradisi lisan, dan setiap titik atau secerca harapan yang memberi penerangan bagi cerita kehidupan manusia.

Dalam melakukan pengumpulan sumber, penelitian menempuh dua cara:

\section{a. Penelitian pustaka}

Studi pustaka merupakan salah-satu langkah penting dalam penelitian sejarah. Dalam studi pustaka ini akan di lakukan studi terhadap sejumlah bahan pustaka, baik yang berupa arsip, buku, dan hasil penelitian lainnya yang memiliki kaitan dengan topik penelitian ini.

\section{b. Penelitian lapangan}

Kegiatan yang akan kita lakukan dalam penelitian lapangan adalah mengadakan pengumpulan data secara lansung terhadap objek yang menjadi sasaran penelitian. Metode observasi yaitu pengamatan lansung terhadap objek yang menjadi sasaran penelitian. Metode observasi yaitu pengamatan lansung kelapangan dimana peneliti dapat melakuka pengamatan lansung terhadap objek penelitian yakni di kecamatan Bontonompo. Sedangkan untuk metode wawancaranya dengan melakukan tanya jawab sengan beberapa informan terkait atau yang terlibat lansung dalam hal ini. Dari hasil wawancara dapat di catat dan di rekam secara langsung.

\section{Kritik}

Setelah melakukan pengumpulan data maka langkah yang selanjutnya adalah kritik sumber atau data-data yang di temukan baik dalam penelitian lapangan maupun penelitian pustaka.

Hasil dari penelitian sejarah yang akademis atau kritis memerlukan faktafakta yang telah teruji. Oleh karena itu data- 
data yang telah di peroleh melalui tahapan heuristik harus di kritik atau di saring sehingga di peroleh fakta-fakta yang subjektif mungkin kritik tersebut berupa kritik tentang otentitasnya (kritik ekstern) maupun kredebilitas isisnya (kritik interen). (sejarah, 2013)

a. Kritik eksteern di lakukan untuk menguji keaslian sumber sejarah. Keaslian yang dimaksud adalah hasil bukan tiruan, sumber tersebut dalam arti belum berubah. Sedangkan pada metode wawancara atau sumber lisan di mana informan harus memiliki kemampuan untuk memeriksa keterangan sebenarnya.

b. Kritik interen atau kritik yang dil akukan untuk meneliti sumber yang berkaitan dengan masalah penelitian dan laporan hasil penelitian. Setelah menetapkan sebuah teks otentik dan menemukan apa yang sungguh-sungguh ini di katakan oleh pengarang maka sejarawan baru menetapkan apakah kesaksian tersebut kredibal. (Gottshalk, n.d.) Hasil dari kritik sumber ini baik itu kritik ekstern maupun kritik intern kemudian di tinjau lebih lanjut.

\section{Interpretasi}

Interpretasi adalah proses pemaknaan fakta sejarah dalam interpretase terdapat dua point penting yaitu sintesis (menyatukan) dan analisis (menguraikan). Fakta-fakta sejarah dapat di uraikan dan di satukan sehingga berkaitan dengan makna satu sama lainnya.

Interpretasi merupakan tahapan selanjutnya setelah penulis melalui kritik sumber. Dimana sumber-sumber yang kita dapatkan perlu di tafsirkan oleh peneliti di butuhkan untuk menafsirkan sebuah kejadian berasarkan data-data yang terkumpul. Dalam proses penafsiran peneliti harus benar-benar berhari-hati sehingga tidak terjebak dalam subjektifitas yang kadang kala sangat di pengaruhi oleh hasil penulisan.

\section{Historiografi}

Tahap yang terakhir pada metode sejarah. Setelah sumber di kumpulkan kemudian di kritik (seleksi) menjadi data kemudian di maknai menjadi fakta, langkah terakhir adalah menyusun semuanya menjadi satu tulisan utuh yang terbentuk narasi kronologis.

Historiografi modern (sejarah kritis), seorang sejarawan yang piawai tidak lagi terpaku pada bentuk penulisan yang naratif atau deskripti, tetapi multi dimensionalnya lebih mengarah kepada bentuk yang analitis karna yang di rasakan mengarah kepada bentuk yang analitis karna harus di rasakan lebih scientific dan mempunyai kemampuan memberi keterangan yang lebih unggul dengan apa yang di tampilkan oleh sejarawan konvensional dengan sejarah naratifnya

\section{Pembahasan}

1. Peran dan Kiprah Haji Patarai Daeang Ma'ruppa Sebagai Pegawai Peternakan Tahun 1951

Haji Patarai Daeng Ma'ruppa mengawali karir dengan menjadi pegawai peternakan di kota Makassar dan pada tahun 1951 Haji Patarai Daeng Ma'ruppa dilantik menjadi Pegawai Negeri Sipil (PNS) Dinas Peternakan Kota Makassar. Setelah pengangkatan menjadi Pegawai Negeri Sipil, dia menjalankan tugasnya sebagai pegawai dinas peternakan kota Makassar dengan baik, mengingat sosok Haji Patarai Daeng Ma'ruppa adalah salah satu pegawai yang dikenal memiliki kharisma yang kuat dan memiliki gagasan yang cukup inovatif, lebih banyak bergerak namun jarang bicara menjadi salah satu teladan yang dimilikinya.

Berselang satu tahun masa kerja menjadi pegawai dinas peternakan kota Makassar Haji Patarai Daeng Ma'ruppa dikirim ke Ambon untuk melihat kondisi dan situasi kantor peternakan kota Ambon dan melanjutkan kembali masa bakti menjadi pegawai dinas peternakan, Haji Patarai Daeng Ma'ruppa meninggalkan keluarga, istri dan anaknya di kota Makassar khususnya di kecamatan Bontonompo untuk dikirim ke Ambon. Berselang tujuh tahun masa kerja sebelum 
kembali ke kota Makassar Haji Patarai Daeng Ma'ruppa hanya beberapa kali menengok sanak keluarga, istri dan anaknya untuk sekedar melepas rindu, tanpa ada komunikasi yang terjalin selama berada di Ambon.

Haji Patarai Daeng Ma'ruppa terbilang lama di Ambon untuk melaksanakan tugasnya sebagai pegawai dinas peternakan karena terhitung 7 tahun yaitu di mulai pada tahun 1953-1960, sebelum kembali ke kota Makassar. Setelah Haji Patarai Daeng Ma'ruppa kembali ke kota Makssar beliau mempensiunkan diri sebagai pegawai dinas peternakan. Dan Haji Patarai Daeng Ma'ruppa kembali menjadi masayarakat sipil, rumpun keluarganya yang tidak terlepas dari keluarga karaeng dan bergelut di bidang pemerintahan. Maka pada tanggal 24 Desember 1962 Haji Patarai Daeng Ma'ruppa dinobatkan menjadi Angrong Guru Bontonmpo menggantikan Sinring Manggose Daeng Lira yang telah terlebih dahulu menjabat sebagai Angrong Guru keX. Haji Patarai Daeng Ma'ruppa menjadi Angrong Guru ke-XI sekaligus menjadi Angrong Guru Bontonmpo terakhir di akibatkan system pemerintahan sebelum dilebur atau diubah menjadi desa pasca pergeseran tatanan kebangsaan dari kerajaan menjadi republik. Kemudian masa pemerintahan Haji Patarai Daeng Ma'ruppa menjadi Angrong Guru Bontonompo berakhir pada tahun 1967.

Pengangkatanya sebagai Angrong Guru selepas menjadi pegawai dinas peternakan kota Makassar tidak terlepas dari campur tangan keluarga dan keahlian Haji Patarai Daeng Ma'ruppa dalam kepemimpinan ini terlihat dari sosoknya yang memiliki gagasan yang cukup inovatif, lebih banyak bergerak namun jarang bicara menjadi salah satu talenta yang dimilikinya dan merupakan salah satu tokoh di Bontonmpo yang disegani oleh rakyatnya. Suatu hal yang amat tepat jika seorang Karaeng yang cukup dikenal dan terpandang luas di daerahnya, memiliki keagungan budi pekerti dan keberanian yang perwira pada masanya. Kepala-kepala pemerintahan yang berada di Sulawesi Selatan, sebelum kedudukan kepala atau komandan barisan penerjang dari Gerakan Muda Bajeng di distrik Moncong Komba merangkap pilihan rakyat sebagai Bate (kepala distrik bawahan). (Taba, 2019)

Pada awalnya Jipang, Bontonompo dan Bontolangkasa adalah tiga perkumpulan besar yang mempunyai sistem pemerintahan terdiri dari wilayah ujung selatan Bontonompo, tepatnya di sebelah barat Pattalassang (Kabupaten Takalar). Selain tiga kampung tersebut, terdapat pula tiga daerah yang diperintah oleh seorang Angrong Guru. Akhir dari fase transisi terjadi ketika Gowa yang merupakan daerah Swapraja yang bergabung dalam pemerintahan Afdeling Makassar meminta untuk berdiri sendiri sebagai sebuah daerah Otonom. Gowa bagian selatan yang dipimpin oleh I Yuseng Daeng Mallingakai mengambil alih sendiri kekuasaan dan membentuk wilayah yaitu Bontonompo berdirinya Bontonompo disebab akibatkan oleh, Tubarania, Bungu' Tubarania, Butta Tubarania. Daerah Bontonompo yang dipimpin oleh gelar "Kare" yang berinterigasi dari gelar "Karaeng Leo Maloe" (Karaeng Polombangkeng). (Tutu, 2019)

Masa kemerdekaan pada awal dicetuskannya kemerdekaan Republik Indonesia 17 Agustus 1945 yang menandai penggabungan seluruh daerah nusantara ke dalam negara kesatuan, Rakyat Gowa tampil berjuang mempertahankan kemerdekaan dari ancaman belanda yang ingin kembali menjajah. Daerah Gowa merupakan basis utama gerakan pejuang kemerdekaan seperti Lipang Bajeng. Sejarah pemerintahan Gowa mengalami perubahan sesuai dengan sistem pemerintahan Republik indonesia. Guna memperlancar pelaksanaan pemerintahan dan pembangunan, masyarakat di setiap kecamatan, kecamatan persiapan Bungaya ini kemudian disefinitifkan dengan PP Nomor 34 tahun 1984. Dengan demikian Gowa bertambah menjadi 9 kecamatan. Perkembangan selanjutnya Gowa menjadi 
16 Kecamatan, yakni: Kecamatan Somba opu, Pallangga, Barombong, Bajeng, Bontonompo, Bontonompo Selatan, Bontomarannu, Pattalassang, Parangloe, Manuju, Tinggimoncong, Tombolopao, Bungaya, Bontolempangan, Biringbulu dan Tompobulu. Pada tahun 2005 lalu dibentuk lagi 2 Kecamatan yakni kecamatan Parigi dan Bajeng Barat. (Syarifuddin kulle, 2007)

\section{Peran dan Kiprah Haji Patarai Daeang Ma'ruppa Sebagai Kepala Desa/Lurah Bontonompo.}

Pada tahun 1967 Haji Patarai Daeng Ma'ruppa dilantik menjadi Kepala Desa Bontonompo Kabupatan Gowa dengan sistem pemilihan masyarakat Bontonompo "dari rakyat oleh rakyat untuk rakyat". Haji Patarai Daeng Ma'ruppa mencalonkan diri sebagai kepala Desa Bontonompo setelah berakhir masa jabatanya menjadi Angrong Guru Bontonompo pada tahun 1967. Di mana waktu itu pemilihannya diselenggarakan dengan cara hak pilih rakyat se-Bontonompo dengan memberikan sebutir jagung/satu orang yang akan dimasukkan ke dalam kaleng, yang terdiri dari 2 kaleng masing-masing satu calon memiliki satu kaleng dan rakyat menggunakan hak pilihnya dengan memberikan sebutir jagung itu ke dalam kaleng yang ada di depan masing-masing calon yang diinginkannya.

Haji Patarai Daeng Ma'ruppa mencalonkan diri menjadi kepala desa Bontonompo bersaing dengan Daeng Kampo yang tidak lain adalah keluarga Haji Patarai Daeng Ma'ruppa. Dengan sistem pemilihan itu Haji Patarai Daeng Ma'ruppa unggul dari Deang Kampo, setelah berakhir masa jabatannya menjadi Angrong Guru Bontonompo pada tahun 1967 dengan tahun yang sama beliau dilantik menjadi kepala desa Bontonompo.

Posisi Haji Patarai Daeng Ma'ruppa dalam sistem kemasyarakatan dan pemerintahan di kecamatan Bontonompo terbilang istimewa, faktor ini disebabkan kemampuan manajerial dan pola komunikasi Haji Patarai Daeng Ma’ruppa yang efektif dan penuh dengan ide pembaharuan juga ditunjang oleh rumpun keluarga yang berpengaruh di Bontonompo. Kharisma yang dimilikinya membuat sistem pemerintahan berjalan efektif, rasa keadilan dan kedamaian pun cukup terasa, hal ini bersemi dalam sanubari warga Bontonompo disebabkan kemampuan para pengendali atau pelaksana pemerintahan mampu menjalin harmoni dengan rakyatnya, piawai mengola sistem kinerja dengan mengedepankan saling memahami dan saling mendukung. Hadirnya adab dan etika sosok pemimpin menjadi sebuah momen-momen indah dalam sejarah perjalanan pemerintahan Bontonompo.

Interaksi antar Lintas Desa/Kelurahan dalam satu rasa dan energi sebagai pengabdi pun berjalan maksimal. Bersama beberapa tokoh Bontonompo di antaranya Nasaruddin Daeng Lapang di Bontolangkasa, H Patahang Daeng Sipato di Desa Salajangki, Paharuddin Daeng Nyonri di Desa Jipang, Bangsawan Daeng Lira di Desa Sengka, Bauna Daeng Lallo di Desa Pa'bundukang dan beberapa tokoh lainnya, gerak tatanan pemerintahan Bontonompo saat itu pun masuk dalam fase yang gemilang, interaksi hati dan batin sesama mereka mampu mendorong dan memberikan energi besar bagi perjalanan karir sosok seseorang Syahrul Yasin Limpo untuk mengabdi di ruang birokrasi.

Dinamika politik dan perubahan struktur tatanan kemasyarakatan di Kecamatan Bontonompo dari model feodalistik kemudian berubah ke dalam negara kesatuan ditambah banyaknya tragedi politik kebangsaan, mulai dari pemberontakan PKI Permesta, DI/TII sampai perubahan sikap tokoh masyarakat yang primordial menjadi sebuah tantangan besar dalam menata dan menjalankan roda pemerintahan desa sebagai ujung tombak pembangunan, peran Haji Patarai Deang Ma'ruppa cukup besar. Langkah merangkul semua pihak menjadi salah satu spesialisasi yang dimilikinya, mengedepankan komunikasi hati dengan pihak lain 
merupakan satu hal yang disenanginya. (Mala’lang, 2018)

Dalam data sejarah pemahaman kelurahan dan desa yang disusun oleh Kanin Depdikbudcam Bontonompo, dikemukakan bahwa pada mulanya Kerajaan Jipang berasal dari Karaeng Palili. Dikatakan Karaeng Palili dikarenakan rajanya tidak mempunyai wilayah dan selalu berada di medan perang, yang juga diistilahkan sebagai Karaeng Pakbundu (Raja yang suka perang). Sementara itu yang memegang kekuasaan di kerajaan Gowa adalah I Raja Le Daeng Matanro dengan gelar Tumaparisik Kallonna, di mana sejak dinobatkan sebagai Raja Gowa ke-9 senantiasa berusaha memperluas wilayah kekuasaannya. Baik dengan jalan perang maupun dengan jalan damai. Untuk daerah bagaian selatan telah terbagi dalam beberapa kerajaan kecil, termasuk diantaranya adalah kerajaan Jipang, Bontonompo dan Bontolangkasa yang tidak luput dari sasaran ekspansinya.

Pada tahun 1868 Belanda sudah beberapa kali menyerang Bontonompo, tapi tidak dapat ditaklukkan. Belanda berupaya agar Gaukanga yang menjadi simbol kekuasaan masayarakat Bontonompo

Pada tahun 1966 Haji Patarai Daeng Ma'ruppa menjadi pembina "GAUKANGA" Sabbe Tamammalisina Bontonompo yang merupakan bendera pusaka dan ikon terbesar Bontonompo yang tidak berubah dimakan oleh masa. Gaukanga ri Bontonompo atau Jimaka ri Bontonompo yang umumnya dikenal dengan sebutan "KALOMPOANGA" atau Sabbe Tamammalisikna Bontonompo. Gaukanga ini pada prinsipnya merupakan lambang kebesaran yang berbentuk bendera berupa Pataka dan bermakna "persatuan dari seluruh masyarakat Bontonompo" Bendera Gaukanga ini berukuran 2x 1,5 meter berwarna biru, di dalamnya bergambar 2 pedang bersilang, masing-masing sudut mempunyai bintang segi enam yang di dalamnya tertulis nama Muhammad, Abubakar, Usman, Ali dalam tulisan arab dan pinggiranya tertulis ayat kursi. Pesta-pesta Gaukanga ini disebut “Accera gaukanga” dilaksanakan sebagai penjelmaan atas rasa persatuan dan kesatuan yang ikut menjiwai dan merasakan bagaimana keramatnya Gaukanga ini dari dulu hingga kini. Yang ingin dirampas. Sehingga terjadilah peperangan, yang dikenal dengan Bunduka ri Mangasaya (perang di Mangasa). Perang ini melibatkan masyarakat Bontonompo yang dipimpin oleh I Yuseng Daeng Mallingkai. Setelah peperang (Bunduka ri Mangasaya) ini berakhir dengan kekalahan masyarakat Bontonompo dan mengakibatkan I Yuseng Daeng Mallingkai ditawan kemudian dihukum pancung hingga menemui ajalnya. Dan setelah kekalahan itu maka gelar "Kare" diturunkan menjadi gelar "Angrong Guru”. (Syahul Yasin Limpo, 1995)

Dalam sistem pemerintahan sebelum dilebur atau diubah menjadi desa pasca pergeseran tatanan kebangsaan dari kerajaan menjadi republik, kepemimpinan kerajaan Tojeng, kepemimpinan murni dan lansung yang terdapat di desa-desa, menurunkan gelar-gelar yang berbeda-beda menurut sejarah desa masing-masing. Adapun gelar-gelar penguasa desa terdapat lingkungan kerajaan gowa pada fase terakhir perkembangannya, dapat di gambarkan meliputi : (1) Gallarang, seperti Gallarang Mangasa, Gallarang Tombolo. (2) Angrong Guru, seperti Angrong Guru Lempangngan, Angrog Guru Boncobalang dan Angrong Guru Bontonompo. (3) Daeng, seperti Daeng Palangga, Daeng Paku (4) Jannang, seperti jannang Gentungan, Jannang Data,(5) Aruk, seperti Aruk pao. (Wahid, 2007)

Angrong Guru yang memegang kepala pemerintahan memiliki peran dalam setiap kegiatan yang mengatur semua sistem wilayah untuk pemerintahan koordinatorschap ini dihapus sesuai kebijaksanaan terhadap seluruh wilayah republik indonesia. Bontonompo sendiri terdapat beberapa Angrong Guru yang telah memegang kepemimpinan wilayah yang diturunkan secara turun temurun 
berdasarkan silsilah kekeluargaan secara (Murni) memiliki aliran darah yang di awali oleh (1). I Yuseng Daeng Mallingkai, (2). Poli Daeng Manyyarang, (3). Mannarai Deang Manggemba, (4). Saso Daeng Panakku, (5). Gangga Daeng Manyarreki, (6). I Manynyaurang Daeng Sibali, (7). Pammuntuli Daeng Rombo, (8). Mappasaile Daeng Sija, (9). Mannagarri Daeng Lassa, (10). Sinring Manggose Daeng Lira, (11). Haji Patarai Daeng Ma'ruppa. (Taba, 2019)

Menurut daftar nama-nama yang pernah memerintah sebagai Angrong Guru di kecamatan Bontonompo tercantum di atas ini, maka tampak pemerintahan di masa yang silam telah silih berganti, namun demikian penobatan sebagai Angrong Guru menggantikan Angrong Guru sebelumnya senantiasa masih mempunyai pertalian darah atau hubungan kekerabatan. Hal tersebut rupanya terjadi pula di setiap suatu tempat atau kerajaan lainnya, sedangkan khusus dalam pemerintahan di kecamatan Bontonompo pewarisan tampak pemimpinan telah dilakukan pertama kalinya dari Angrong Guru pertama dari I Yuseng Daeng Malingkai

Pada tahun 1910 pemerintahan Kolonial Belanda mengadakan reorganisasi pemerintahan, kerajaan Gowa yang telah dibekukan itu diubah menjadi Federasi Gowa. Yang terdiri atas 13 (tiga belas) Gemenschap, yaitu: Mangasa, Tombolo, Barangloe, Karuwisi, Pattallassang, Borisallo, Parigi, Manuju, Limbung, Bontonompo, Malakaji, Pao, dan Kindang (wilayah bulukumba sekarang) (Najamuddin et al., 2009; Najamuddin, 2015)

Haji Patarai Daeng Ma'ruppa sebagai kepala Desa Bontonompo terbilang lama karna berlansung selama 15 tahun kepemimpinan yaitu pada tahun 19671979, pada tahun 1979 Desa Bontonompo diubah menjadi kelurahan. Haji Patarai Daeng Ma'ruppa yang pada waktu itu menjabat sebagai kepala desa Bontonompo mengambil alih pemerintahan di kelurahan Bontonompo, pada tahun 1981 Haji
Patarai Daeng Ma'ruppa resmi dilantik menjadi Lurah Bontonompo sekaligus menjadi lurah pertama di Bontonompo Kec.Bontonompo Kab.Gowa. Mengingat Haji Patarai Daeng Ma'ruppa lahir dari keluarga yang memiliki jiwa kepemimpinan maka jejaknya memegang kendali tatanan pemerintahan di Bontonompo terbilang gemilang. Haji Patarai Daeng Ma'ruppa memiliki jiwa keadilan pada dirinya sehingga selama masa jabatannya baik menjadi kepala Desa maupun Lurah Bontonmpo dapat memakmurkan rakyatnya, juga merupakan salah satu inisiator berdirinya komunitas ikatan keluarga besar Bontonmpo "Ikambe" yang merupakan wadah dari perhimpunan seluruh tokoh ternama dan perpengaruh di Bontonompo.

Dalam bidang ekonomi Haji Patarai Daeng Ma'ruppa juga memiliki peran penting di Bontonompo yaitu Pada Tahun 1988 Haji Patarai Daeng Ma'ruppa bersama beberapa sahabatnya menata ekonomi Bontonompo dengan sebuah wadah ekonomi rakyat bernama Koperasi yang di beri nama Koperasi Unit Desa (KUD) Bontonompo. Kehadiran unit ekonomi rakyat tersebut mampu menjadi wadah perekat nilai kebersamaan dan persatuan para aparat pemerintahan dan masyarakat khususnya kalangan aparatur pegawai saat itu. dan Haji Patarai Daeng Ma'ruppa sebagai penggagas dan pendiri KUD. Setelah mendirikan KUD Bontonompo pada tahun 1996 Haji Patarai Daeng Ma'ruppa menjadi Ketua Yayasan Mesjid Besar Raodatussalihin Bontonompo yang telah di dirikan oleh Poli Daeng Manyyarang sebagai Angrong Guru Bontonompo ke-II bersama para Angrong Guru lainnya yang diyakini sebagai mesjid tertua ke-2 dari mesjid katangka mesjid tertua pertama. Haji Patarai Daeng Ma'ruppa diberikan kepercayaan menjadi ketua yayasan masjid Raodatussalihin Bontonompo, karena dilihat dari dedikasi yang telah diberikan beliau kepada rakyat Bontonompo dan tidak lain masjid Raodatussalihin didirikan oleh Poli Daeng 
Manyyarang yang tidak lain adalah keluarga sendiri dari Haji Patarai Daeng Ma'ruppa. Mesjid Raodatussalihin juga tidak dapat terlepaskan dari Angrong Guru Bontonompo yang merupakan penggagas berdirinya masjid besar Bontonompo.

Pada tanggal 01 Maret 1987 Haji Patarai Daeng Ma'ruppa mengakhiri masa jabatannya sebagai lurah Bontonompo dengan masa bakti selama 7 tahun kepemimpinan kemudian digantikan oleh anaknya yang bernama Drs. Mulya Dharma Patarai Deang Ngewa periode 1987-1988 sebagai Lurah kedua Bontonompo setelah menggantikan ayahnya sebagai Lurah pertama Bontonompo. (Taba, 2019)

\section{Kesimpulan}

Latar belakang keluarga Haji Patarai Daeng Ma’ruppa, Pada tanggal 02 Februari 1942 pasangan suami istri I Manynyaurang Daeng Sibali dan Camu Deang Nginai melahirkan seorang putra yang di beri nama Patarai Deng Ma'ruppa yang akrab di sapa Kare Ruppa. Gelar itu di ambil dari ayahnya yang merupakan Genetika Gallarang Bontonompo dan pada tahun 1982 beliau melaksanakan ibadah haji yang merupakan rukun islam ke-5 dan mendapatkan gelar Haji pada namanya. Haji patarai Daeng Ma'ruppa beristrikan Hajja Hadijah Daeng Labbi anak imam Bontonompo yaitu Madatuang Kare' Tawang

Peranan dan Kiprah Haji Patarai Daeng Ma'ruppa meliputi: (1) PNS dinas peternakan kota makassar pada tahun 1951. (2) Angrong Guru Bontonompo yang ke XI mulai tanggal 24-12-1962 sampai 1967. (3) Kepala desa Bontonompo Kecamatan Bontonompo Kab.Gowa tahun 1967-1981. (4) Lurah Bontonompo Kecamatan Bontonompo Kab.Gowa tahun 1981-1987. (5) Ketua K.U.D Bontonompo tahun 1988. (6) Ketua yayasan mesjid besar Raodatussalihin Bontonompo tahun 1996. (7) Pembina "Gaukanga" tahun 1966. (8) Pemangku adat Kecamatan Bontonompo Kab. Gowa 2003.
Peran dan Kiprah Haji Patarai Daeng Ma'ruppa ketika memegang kendali dalam pelestarian Gaukanga dan pemangku adat di Bontonompo terbilang gemilang, Haji Patarai Daeng Ruppa adalah salah satu tokoh di Bontonompo yang dikenal memiliki kharisma yang kuat, disegani juga disayangi oleh rakyatnya. Punya gagasan yang cukup inovatif, lebih banyak bergerak namun jarang bicara menjadi salah satu talenta yang di milikinya, Haji Patarai Deang Ma'ruppa juga merupakan salah satu inisiator berdirinya komunitas ikatan keluarga Besar Bontonompo "ikambe" yang merupakan wadah dari perhimpunan seluruh tokoh ternama dan berpengaruh di Bontonompo.

\section{DAFTAR PUSTAKA}

Gottshalk, L., n.d. Mengerti sejarah. Jakarta: Yayasan penerbit Universitas Indonesia.

Kila, S., 2004. Sejarah Gowa 1969-1799. Makassar: s.n.

Kuntowijoyo, 2005. pengantar ilmu sejarah. Yogyakarta: Benteng.

Majid, A. R. H. d. M. S., 2018. Pengantar ilmu sejarah. Makassar: Rayhan Intermesdia.

Mala'lang, Y. K. D., 2018. Sejuta Lentera dari Butta Bontonompo.

Bontonompo: Yayasan Punggawa Kalase'rena.

Muhamad Arfah, d., 1995. Sejarah Perjuangan Bangsa Di Daerah Sulawesi Selatan. s.l.:s.n.

Najamuddin, N. et al. (2009) 'Sulawesi Selatan Tempo Doeloe (Muzaik sejarah Lokal)'. Raihan Intermedia.

Najamuddin, N. (2015) 'Persaingan Elit Bangsawan dengan Kelompok Terdidik pada Masa Revolusi di Sulawesi Selatan', Istoria: Jurnal Pendidikan dan Ilmu Sejarah, 11(1).

Sahajuddin, 2009. Bantaeng Pada Masa Kolonial Belanda Periode 19051945Dapertemen Kebudayaan dan Pariwisata Balai Pelestarian Sejarah 
dan Nilai Tradisional Makassar.

Makassar: Dapertemen

Kebudayaan dan Pariwisata Balai

Pelestarian Sejarah dan Nilai

Tradisional Makassar.

Sejarah, T. p. j. p., 2013. pengantar ilmu sejarah. Makassar: Balai penerbit UNM.

St.Nuraeda, 2008. Pahlawan Nasional Dari Sulawesi Selatan. s.l.:s.n.

Syahrul Yasin Limpo, d., 1995. Profil Sejarah Budayaa dan Parawisata Gowa. Ujung Padang: INTISARI.

Syahul Yasin Limpo, A. S. C. Z. T., 1995. Profil Sejarah Budaya Dan Parawisata. Ujung Pandang: INTISARI.

Syarifuddin kulle, Z. T. N., 2007. Gowa Bergejolak, Gerakan Rakyat Menantang Penjajah. s.l.:Karya Gowa.

Taba, S. P. K., 2019. Wawancara [Interview] (22 Juli 2019).

Tutu, M. D., 2019. Wawancara [Interview] (21 Juli 2019).

Wahid, S., 2007. Manusia Makassar. Makassar: Refleksi. 
PATTINGALLOANG

(C) Jurnal Pemikiran Pendidikan dan Penelitian Kesejarahan 